\title{
Commentary
}

\section{The True North Strong and Free? \\ Casting Shadows on Whose History Students Learn in Canadian Universities}

\author{
Amy Barlow ${ }^{1}$ and Fiona Edwards ${ }^{2}$ \\ ${ }^{1}$ Ph.D. Candidate, York University, Department of Politics, Toronto, Ontario, Canada \\ ${ }^{2}$ Ph.D. Candidate, York University, Department of Social Work, Toronto, Ontario, Canada
}

This is a peer-reviewed (double-anonymized) article

Published online: 24 November 2021

(C) The Author(s) 2021. This article is published with a Creative Commons Attribution license (CC BY 4.0)

https://creativecommons.org/licenses/by/4.0/. It is published with open access at https://inyi.journals.yorku.ca

ISSN: 1929-8471

DOI: https://doi.org/10.25071/1929-8471.83

\begin{abstract}
Race-based discrimination in Canada exists at the institutional and structural level. While acknowledging its existence is a crucial first step in eradicating this particular form of discrimination, an essential second step includes implementing structural changes at the institutional level in Canadian universities. In an effort to disrupt the Eurocentricity of knowledge production this commentary argues that the Canadian government's official historical narrative that depicts Canada as being born of the pioneering spirit of British and French white settlers fails to capture the actual history of the country. Rather, it fosters the continuation of the supremacy of whiteness thereby causing significant harm through the perpetuation of racial bias. We argue that the history and contributions of Indigenous, Black, and Chinese Canadians, all of whom were in this country prior to confederation, should be told in a mandatory university course. Our findings indicate that while a number of universities have individual courses, usually electives and some graduate degrees on Indigenous, Black, and Chinese history, there is little offered from the Canadian context and certainly nothing that is a mandatory course requirement. In addition, we suggest compulsory university staff-wide anti-racism training; the ongoing hiring of professors and sessional instructors who are racially representative of the population of Canada; and community outreach, mentorship, and counselling programs that are designed to help students who are underrepresented in Canadian universities. In our opinion, we believe that these changes have the potential to provide a lens to disrupt settler colonial spaces, mobilize race in academic curricula, and encourage social justice actions that can offer a more inclusive learning environment.
\end{abstract}

Keywords: Youth, anti-Black racism, Anti-Indigenous racism, anti-Chinese racism, Education, Canadian history, University education.

Résumé: La discrimination fondée sur la race au Canada existe au niveau institutionnel et structurel. Bien que la reconnaissance de son existence soit une première étape cruciale dans l'éradication de cette forme particulière de discrimination, une deuxième étape essentielle consiste à mettre en œuvre des changements structurels systémiques au niveau institutionnel dans les universités canadiennes. Dans un effort pour perturber l'eurocentricité de la production de connaissances, ce commentaire soutient que le récit historique officiel du gouvernement canadien qui dépeint le Canada comme étant né de l'esprit pionnier des colons britanniques et Français blancs ne parvient pas à saisir l'histoire réelle du pays. Au contraire, il favorise le maintien de la suprématie de la blancheur, causant ainsi un préjudice important par la perpétuation des préjugés raciaux. Nous soutenons que l'histoire et les 
contributions des Canadiens autochtones, noirs et chinois, qui étaient tous dans ce pays avant la Confédération, devraient être racontées dans un cours universitaire obligatoire. Nos résultats indiquent que, bien qu'un certain nombre d'universités offrent des cours individuels, habituellement au choix, sur l'histoire autochtone, noire et asiatique, le contexte canadien offre peu de cours et certainement rien qui soit une exigence de cours obligatoire. De plus, nous suggérons une formation obligatoire sur la lutte contre le racisme à l'échelle du personnel universitaire; l'embauche continue de professeurs et d'instructeurs de session qui sont représentatifs de la population du Canada; et des programmes communautaires de sensibilisation, de mentorat et de counseling conçus pour aider les étudiants sous-représentés dans les universités canadiennes. À notre avis, nous croyons que ces changements ont le potentiel de fournir une lentille pour perturber les espaces coloniaux des colons, mobiliser la race dans les programmes d'études et encourager les actions de justice sociale qui peuvent offrir un environnement d'apprentissage plus inclusif.

Mots-clés: Jeunesse, Racisme Anti-Noirs, Racisme anti-autochtone, Racisme anti-Chinois, Éducation, Histoire Canadienne, Enseignement universitaire.

Corresponding author: Amy Barlow York University, Toronto, Ontario, Canada Email: amybarlo@yorku.ca 


\section{Introduction}

Race-based discrimination in Canada exists at the institutional and structural level (Este \& Sato, 2018; James et al., 2010). While acknowledging its existence is a crucial first step in eradicating this particular form of discrimination, an essential second step includes implementing structural changes at the institutional level in Canadian universities. Using an anti-racism framework, and adopting a critical race theoretical lens, this commentary seeks to challenge the Canadian government's official historical metanarrative that depicts Canada as being born of the pioneering spirit of British and French white settlers. This fictional metanarrative is problematic as it excludes the experiences and contributions of Indigenous, Black, and Chinese Canadians. Our decision to include these peoples is twofold. First and foremost, teaching the actual history of the Indigenous peoples of this land is central to our understanding of this country, second, both Black and Chinese peoples have been in this country prior to confederation. Moreover, all three groups have been virtually erased from the official overarching historical metanarrative. It is important to note that positioning these three groups together is not meant to diminish their individual importance, but rather, it is meant to acknowledge their existence and experience in the history of Canada.

As university level educators, we engage in critical research and knowledge mobilization with the central aim of challenging the Eurocentric production and reproduction of knowledge. It is from this position that we argue that the omission of these histories erases an integral part of Canadian history that fosters the continuation of the supremacy of whiteness causing significant harm through the perpetuation of racial bias. We are inspired by the Truth and Reconciliation Commission's (TRC) recommendations to educate Canadians about Indigenous Peoples' experiences in residential schools and intergenerational trauma (Truth and Reconciliation Commission, 2015). However, we suggest going a step further by expanding on the primary school and high school educational recommendations to include a more accurate overview of the history of Canada at the university level. At this point, it is important to say, that our proposals are just one possible constellation of actions that could be taken to mitigate the perpetuation of white supremacy. This commentary is not meant, by any means, to provide the only solution to a complex set of problems. Rather, our intention is to have it serve as a potential entry point from which to disrupt the Eurocentric production and reproduction of knowledge in Canada.

In this commentary we propose several institutional level changes that are designed to affect real and lasting change that include: a country-wide addition of a mandatory first year university course that incorporates the history of these three groups within the Canadian context; a provision for mandatory university staff-wide anti-racism training; the ongoing hiring of professors and sessional instructors who are racially representative of the population of Canada; and community outreach, mentorship, and counselling programs that are designed to help students who are underrepresented in Canadian universities. In our opinion, we believe that these changes will provide a lens to disrupt settler colonial spaces, mobilize race in academic curricula, and encourage social justice actions that have the potential to offer a more inclusive learning environment. We acknowledge that some Canadian universities have implemented Diversity, Equity, and Inclusionary (DEI) frameworks and training sessions. However, the literature suggests that in many cases such efforts are ineffective. What we advocate for is structural change that institutes DEI frameworks at the organizational cultural level (Kepinski \& Hucke, 2017; Maitland \& Steel, 2020; Martinez, 2015; TD Diversity and Inclusion, 2015).

\section{Official Canadian Governmental Narrative of the History of Canada}

The official governmental metanarrative of Canadian history is one that portrays the country as being 'founded' by the pioneering spirit, hard work, and resourcefulness of white settlers from both Britain and France (Government of Canada, 2015). This perspective is presented in history books, films, literature, and popular cultural symbols. It is a perception that mythologizes the history of Canada as a country that is 
good, kind, fair, inclusive, and colourblind. This history of Canada is one that is steeped in myths and symbolism. The country is imagined as being born from the hard work, perseverance, and ingenuity of distant (white) ancestors who built a thriving and bountiful nation out of nothing but a harsh wilderness (Government of Canada, 2015). This historical metanarrative evolved over time whereby Canada is deemed to be a country that is a bastion of democracy where equality is paramount and realized through the law, education, and universal healthcare. The unofficial motto of peace, order, and good governance is an example of the myth of Canada. It is a metanarrative that conjures a history that bears little, if any resemblance, to the historical and contemporaneous reality of the settler colonial country now known as Canada.

This fictional metanarrative casts a shadow on the realities that Indigenous and racialized peoples experience on a daily basis. Encounters that are made visible through the everyday violent interactions that occur between white settlers, white settler agents, and these groups. We argue that this fictional metanarrative should be cast aside and replaced with an accurate history of Canada. This history should include the full and unabashed recounting of the oppressive measures that were, and continue to be, perpetrated against these peoples by white settler governmental structures, their agents, and white settler society (Razack 2012, 2020).

The history of Canada is one that was violent and destructive (Andersen 2015; Green 2006; Hogarth \& Fletcher, 2018). It is well past time to acknowledge the uncomfortable truth that imperial white settler colonial Canada was created on assumptions of white supremacy and white settler nationalism, the reverberations of which are felt to this very day (Mamdani, 2015; McLerran, 2019; Veracini, 2010; Wolfe, 2006). From the genocide of Indigenous Peoples to the enslavement of Black people, and the discrimination against Chinese Canadians the historical record is one characterized by dehumanization and gross violations of human rights.

We firmly believe that the imperial legacy of white supremacy remains deeply rooted in the very fabric of Canadian society. The harms that have been committed and continue to be committed must be acknowledged in their entirety if we are to have any hope of becoming a truly inclusive country. There is no doubt that as a settler colonial country, Canada, has never actually acknowledged its true history in a meaningful way, but rather it has sidestepped responsibility by claiming innocence through denial. For us, identifying the existence of race-based discrimination is not enough. What we advocate for is active engagement that seeks to bear witness to our country's shameful past and its present day legacy. Real change, enduring and lasting change, is only possible if we get to the root of the problem, and we argue that the root is bound up with racial bias that further embeds systems of white supremacy at the structural and institutional level in numerous settings, including education (Delgado, \& Stefancic, 2001, 2013; Razack, 2012, 2020; Tator \& Henry, 2010).

\section{Understanding Racial Bias}

Understanding how racial bias is produced and reproduced is integral to making the systems of white supremacy visible in society in general and in university settings in particular. Racial bias refers to the ways in which people make race-based assumptions, on a dayto-day basis, about who a person is based on virtually no information other than their appearance (Leary, 2005; Stevenson, 2014). These biases are informed by way of stereotypes that are made visible through various social interactions, the language that we use, and the institutional structures that comprise settler colonial Canada (Delgado \& Stefancic, 2001, 2013; Razack, 2020). Racial bias assumes difference rather than similarity, even when similarity is more likely in areas such as upbringing, values, family, education, careers, and general interests (Stevenson, 2014). Racial bias encompasses microaggressions which can be expressed as microassaults, microinsults, and microinvalidations (Sue et al., 2007). For example, microassault includes racial slurs or non-verbal actions that are used to inflict harm, microinsults are negative connotative words about racialized people that question their skills and abilities, and microinvalidations "exclude, negate or nullify the psychological thoughts, feelings or experiential reality of a person of colour" (Sue et al., 2007, p. 274). 
Racial bias posits a binary view of us and them, of what is safe and what is dangerous, what is accepted as knowledge production and what is not, whose experiences matter and whose are discounted, and what is to be respected and what is to be disrespected. For instance, within the Canadian educational system, from kindergarten to university, Eurocentric knowledge is given primacy. At the university level this is evident in the courses that are taught and the research methods that are accepted and employed to produce knowledge, many of which lack Indigenous, Black, and Chinese experiences and ways of knowing. Racial bias is a cognitive shortcut that is informed by a deeply ingrained set of essentialist assumptions that are built on the foundation of white supremacy (Sussman, 2014). As critical race theorists remind $u s$, the overt racist is not necessary in such a conceptualization, as racism exists and persists in the very fabric of society (Crenshaw, 2010; Delgado \& Stefancic, 2001, 2013).

\section{Inclusive Canadian History is Central to University Education}

In our humble opinion, we cannot speak of Canadian history without acknowledging the struggles, hardships, and contributions of Indigenous, Black, and Chinese Canadians. To do so, is revisionist history that denies the realities of colonization, its structure, and its harmful legacy. A decolonizing approach to education at the university level aids in the deconstruction of Eurocentric knowledge production. To the world, and to many Canadians, the nation is envisaged as an exemplar of liberal social democratic capitalist ideals. It is a country that is immune to racism, strongly embraces a multicultural society, and is tolerant and accepting of differences (Hogarth \& Fletcher, 2018). These misperceptions of Canada conceal its inhumane treatment of Indigenous, Black, and Chinese Canadians and others on its soil. It obscures the fact that Indigenous and Black people were enslaved in New France and after the British conquest of 1763, that genocide was committed against the Indigenous population, and that Chinese workers were considered expendable (Canadian Museum for Human Rights, n.d.). It is through the concealment of these facts, and others, that the myth of
Canada can be preserved - it is this concealment that we hope to reveal.

Although the experiences of the groups we speak of are well recorded, an extensive search of foundations courses at Canadian universities indicates that courses from Indigenous, Black, or Chinese perspectives are only available as electives, or are only offered in specialized programs of study. This omission leads us to ask: who decides what should be taught as Canadian history? Canadian history is dominated by white settler colonial narratives that legitimize Eurocentric epistemology that is prevalent and widely accepted in university curricula. This continued Eurocentricity enables the production of knowledge that maintains the status quo, whereby whiteness is upheld as superior while Indigenous and other racialized groups are considered inferior (Vallée 2018). Instituting a mandatory foundational Canadian history course that is inclusive of Indigenous, Black, and Chinese Canadian history could potentially mitigate the many years of exposure to false narratives and lead students to reflect more critically on who they are as Canadians. Simultaneously it has the potential to foster the rise of race consciousness, which in turn can dismantle the underlying systems that uphold the supremacy of whiteness. We believe that including the historical experiences of these people in such a course can help facilitate a better knowledge base for all students, heighten levels of compassion and empathy, encourage connectivity, and lead to a more fulsome understanding of Canada through the acknowledgement of the struggles and accomplishments of these communities.

The current dominance of Eurocentric epistemology in education at the university level may not give Indigenous, Black, and Chinese university students a strong foundation of their histories. This is crucial, as not knowing one's own history can create a false sense of belonging that can produce feelings of isolation, helplessness, and shame about one's identity and community. Having additional exposure to their own histories can help marginalized students contextualize their lived experiences within an historical frame of reference and diversifying educational materials can contribute to a more equitable distribution of knowledge. 


\section{True North Strong and Free - Canadian History?}

The history of Canada has been largely taught at the elementary school, high school, and university level from a white settler perspective that has effectively erased the struggles and contributions of Indigenous, Black, and Chinese people. The real history of Canada cannot be understood without the inclusion of the history of these groups. The Canadian government appears to have taken seriously the 94 Calls to Action from the Truth and Reconciliation Commission (TRC) 2015 by instituting the mandatory age-appropriate education of residential schools and their harmful legacy to elementary and high school students (Government of Canada, 2021). While we have yet to see how this history will be implemented, it appears that teachers can use their discretion, such an approach is not without numerous problems and only time will tell how this policy initiative fairs. We acknowledge that the government's mandate has progressed in the right direction in this regard, however, universities have autonomy over their own curricula. That being said, we do not dispute the fact that some universities have made significant efforts to institute individual courses and programs. These are important efforts, however, what we are proposing, as outlined below, is a mandatory history course at the university level that reflects the actual history of Canada.

The history of Indigenous Peoples, who include First Nations, Métis, and Inuit, and all of the various nations that fall under these groups prior to, and after the first contact is rich and includes complex social, political, and justice structures, religion, medicine, and ways of knowing. This history has been concealed from Canadian consciousness, largely due to racialized assumptions of who Indigenous Peoples were, and are, to this very day. The racialized assumptions that we speak of assumed, and continue to assume, the superiority of whiteness and the inferiority of Indigeneity. It imposed a system of imperial governance, made genocide possible, and justified the aggressive assimilationist policies that sought to eradicate a culture and a people (Andersen, 2015; Byrd, 2011; Logan, 2015; Cannon \& Senseri, 2011; McCallum 2012). The legacy of which continues to this day very through the continuation of settler colonial policies and intergenerational trauma that is a direct result of slavery, land grabs, residential schools, the $60 \mathrm{~s}$ Scoop, involuntary sterilization, poisoning of the water, land, and ultimately people of the Grassy Narrows First Nation, the disproportionate number of Missing and Murdered Indigenous Women and Girls, addiction, endemic levels of suicide, the Millennial Scoop, disproportionately high levels of incarceration, and the continued systemic and institutionalized racial discrimination that exists in Canada. Despite these harsh realities Indigenous resistance and resilience remains strong and has continued for over 500 years as evidenced by the American Indian Movement of the 1970s, Oka, Ipperwash, Elsipgtog, Idle No More, and many, many others. The institution of numerous Indigenous Studies Programs at various Canadian universities are incredibly important, however, these courses are either electives or for people who seek out these degrees. There can only be reconciliation with truth, in doing so, wounds have the potential to heal.

Black peoples' history in Canada is rooted in a legacy of slavery which was legalized in 1689 (Trudel, 1994). This history is characterized by racial discrimination, antiBlack racism, racial segregation, and systems of white supremacy that created systemic barriers for the advancement of Black people (Cooper, 2007; Hogarth \& Fletcher, 2018; James et al., 2010). Black resilience and resistance are a significant part of the Black experience as demonstrated in the life of historical figures such as Marie-Josèphe dite Angélique and Viola Davis Desmond. The Black Power Movement of the 60s and 70s created a pivotal moment in Canadian Black history. Its agenda encompassed the fight against white imperialist hegemony and for raising Black consciousness of anticolonial struggles (Austin, 2007). Using education as a medium of resistance, Black students at the university level protested against the lack of representation of Black faculty members and for more Black courses to be offered to students (Austin, 2007). Actions taken by Blacks to fight against systemic oppression have generated a degree of change within Canadian education institutions. To date, there is an increase in the number of Black faculty members and Black courses offered in universities across Canada. That being said, much more work is required to establish Black studies as a prominent area of scholarship at the university level. 
With respect to Chinese Canadians, the earliest Chinese people arrived in Nootka Sound, Vancouver Island in the 1780s (Ma \& Cartier, 2003). A larger number of Chinese people settled in Canada in the late 1800s in response to the demands of the labour force needed for the period known as the gold rush ( $\mathrm{Li}, 1995$; Hogarth \& Fletcher, 2018). They were recruited in large numbers as cheap and expendable labour to build the Canadian Pacific Railway, when they were no longer required, immigration was virtually brought to a halt through a head tax that was tantamount to a racialized immigration ban (Hogarth \& Fletcher, 2018).

The significant contributions Chinese Canadians have added to the fabric of Canadian society is in the development of essential infrastructures, chief among them is the railway in British Columbia where they initially settled upon arrival (Lim, 2006). Despite their significant contributions to the history of Canada, they faced and continue to face racial discrimination, yet they prevail and have helped Canada's economy boom through various entrepreneurial undertakings that continue today. The resilience of Chinese Canadians is important and can empower their members and communities to tackle institutional discrimination. One of the ways of fighting systemic discrimination is to make visible the strengths of the Chinese culture and their contributions in Canada. Incorporating the histories of the Chinese people in the curriculum is one way of building a sense of pride in its people (Ngo, 2018; Mar, 2007). Their histories need to be made more visible in university curriculum across Canada and at all levels of education as a means to deconstruct stereotypical views and prejudices.

Through the inclusion of Indigenous, Black, and Chinese Canadian historical experiences, some of which are discussed above, we are provided with a more accurate and thorough account of the history of Canada. In doing so, we can facilitate positive change in university wide curricula, the benefits of which we outline below with our recommendations.

\section{University Wide Institutional and Curriculum Change Recommendations}

We acknowledge that reforms to education have been made with the creation of departments, courses, and degrees that focus on Indigenous, Black, and Chinese studies, but further reforms are required. To date, some of what is offered include Indigenous studies programs and courses at the University of Alberta, including graduate studies at the Ph.D. level; the University of Toronto offers graduate studies at the Ph.D. level; Simon Fraser University offers a Master's degree; the University of Saskatchewan offers a Master's degree; the First Nations University offers degrees in Indigenous studies, and the University of British Columbia offers courses on Indigeneity. The focus of these departments and courses varies widely and includes the following: education, languages, art, childcare, community development, criminal justice, Aboriginal governance, Aboriginal health, and Aboriginal history.

With respect to Black studies in Canada, to date, Dalhousie University and York University are reported to offer the only two Black studies programs in Canada (Orford, 2021). Black Canadian history scholar, Dr. Afua Cooper has been instrumental in creating a minor in Black studies at Dalhousie University, which is in the process of becoming a major (Cooper, 2021). Dr. Cooper notes that:

Including Black studies within the curricula of universities and colleges would mean not only rolling out an interdisciplinary program from social sciences and humanities, but also employing a transdisciplinary approach that would cut across faculties such as law, social work, the hard sciences, engineering and health fields. Public history and engagements with community and governments would also form part of this effort (Cooper, 2021, para.17).

York University has been innovative in its creation of the Harriet Tubman Institute, which is intended to increase the production of Black scholarship. In addition, the university also offers a Black Canadian Studies Certificate and Black Studies and Theories of Race and Racism at the graduate level through the Humanities Department (Francis, 2019). Brock University and Carlton University have an Honors BA in African Studies; McGill University 
has a BA in African Studies; Trent University has an African Studies specialization that students can add to their degree; the University of British Columbia has an African Studies minor in the Faculty of Arts; and the University of Toronto offers minors, majors, and specialization in African studies (Orford, 2021). While we credit the development of African Studies programs, their focus is on Africa, very few universities have dedicated Black Canadian studies programs (Francis, 2019).

With respect to Asian studies, a number of universities in Canada have departments that broadly focus on the area. The schools include the following: Grant MacEwan University, University of Calgary, University of Alberta, University of British Columbia, Simon Fraser University, University of Victoria, University of Toronto, York University, Kwantlen Polytechnic University, University Manitoba, University of Winnipeg, University of New Brunswick, St. Mary's University, McMaster University, University of Ottawa, Huron University College, Carlton University, University of Prince Edward Island, McGill University, Concordia University, and the University of Regina. Each of these universities offer a variety of courses and degrees that span undergraduate minors, majors, and specialization, and graduate degrees including at the Ph.D. level. That being said, one of the arguments that has been made about the abundance of these courses and programs is that they are designed to attract Asian students to come to Canada to study who pay very high international student fees. In addition, should these students wish to stay in Canada, they are provided with a fast track to citizenship (Zha, 2019). However, they do not address the Chinese experience in Canada.

While the institution of these courses and departments are important, they do not address the actual history of Canada. What we are advocating for is the inclusion of a foundational course that would be mandatory in all Canadian universities that includes the numerous contributions and the harsh realities that Indigenous, Black, and Chinese Canadians have faced and continue to experience by addressing the following: colonization, settler colonialism, genocide, land dispossession, slavery, aggressive assimilation policies, racial discrimination, segregation, anti-Indigenous, anti-Black, and anti-Asian racism, and their connection to the present forms of marginalization and oppression that persist in Canada. We take seriously the Indigenous principle of 'nothing about us without us' and consequently, this course should be designed by Indigenous, Black, and Chinese Canadian scholars who will be able to determine what is important and indeed necessary to include.

We embrace a critical race theoretical approach and anti-racism framework to address the issues we have highlighted in the curricula at Canadian universities. There are a wide variety of individual departments and courses in Canadian universities that use critical race theory as an analytical lens to examine various sites of inequity and discrimination. In keeping with the tenets of critical race theory, the course that we are advocating for would be designed to further challenge the structural arrangements at the institutional level that maintain systems of oppression. We acknowledge that institutional change is very difficult to accomplish. This is in part due to policies such as affirmative action hiring practices, that at times, have failed to address institutional changes at the structural level. Such hiring practices largely have a primary focus on the number of people hired in an effort to reduce race and gender disparities, rather than implementing measures that can affect actual institutional change (Maitland \& Steel, 2020).

Our proposed course is premised on the educational requirement of a Diversity, Equity, and Inclusionary (DEI) framework, which is derived from critical race theory. For example, one of the primary tenets of critical race theory is to challenge the existing structural inequities that exist in society (Delgado \& Stefancic, 2001, 2013). We believe that education can be a transformative vehicle to affect large scale ideological and institutional change by challenging the status quo. We envision the proposed course to augment existing DEI and anti-racism frameworks in Canadian universities by making learning more inclusive. An anti-racism framework offers insights into how to transform and make the education system more just (Dei, 1999). It is premised on the notion that a critical approach can respond to the marginal experiences of ethnoracial minorities' educational needs, by mobilizing race as a significant factor in its 
analysis of how institutional power produces racial inequalities and inequities in learning outcomes.

By grounding the course in critical race theory and antiracism framework, it would have the ability to address the inequalities and inequities encountered by Indigenous, Black, and Chinese students, among others. In doing so, we have the potential to dismantle asymmetric power relations and inequities that are a direct result of the systems of white supremacy that are rooted in the institutions and structures of Canada. The educational curricula should be representative of its diverse student population at the institutional, practice, and course levels.

We are of the opinion that education can and should act as the impetus for positive social change. The course that we envisage not only tells the truth about the origins of modern day Canada, but also has the ability to help students reflect on their own positionality, irrespective of the negative stereotypes that they may encounter. This course would be mandated and funded by the federal government in all Canadian universities and would have the added advantage of enriching and furthering the scholarship of Black, Indigenous, and Chinese Canadian's and the larger BIPOC community. It could also foster an understanding of how racism is produced and reproduced, where it exists at all levels of practice, and could guide students in tackling this issue at all entry points.

\section{Conclusion}

Throughout this commentary, we have highlighted the need for changes to the Canadian university system that incorporates a mandatory course that accurately covers the actual history of Canada. This history includes the struggles, hardships, and accomplishments of Indigenous, Black, and Chinese Canadians. By teaching the history of Canada, such a course has the potential to better equip students to understand their experiences and place in society.

We fully acknowledge that large scale institutional change is very difficult, however, we subscribe to the belief that it is possible and desirable. The changes we are advocating for, from the viewpoint of critical race theory and an anti-racism framework are guided by the principles of DEI and social justice are desperately needed at this time of increased race consciousness within the Canadian context. The longevity of the proposed course would be sustained through the increased support of Indigenous, Black, and Chinese scholarship in conjunction with mandatory anti-racism training, hiring tenure track and sessional instructors whose expertise can lead to greater engagement in university students learning about their history in Canada, and community outreach, mentorship and counselling programs that are designed to provide students with the opportunity to succeed. Moreover, the course we propose can aid in the development of race consciousness among students in the education system as a powerful tool to dismantle racial biases, thereby removing the shadow and counteracting the Eurocentric of perspectives that Canadian students learn in university. In turn, this benefits Canadian society writ large by disrupting colonial spaces, mobilizing race, and providing space for social justice through a more inclusive learning environment.

Open Access This article is distributed under the terms of the Creative Commons Attribution License (CC BY 4.0, https://creativecommons.org/licenses/by/4.0/) which permits any use, distribution, and reproduction in any medium, provided the original author(s) and the source are credited.

*The authors have no conflicts of interest to disclose.

\section{References}

Andersen, C. (2015). Global Indigeneity, global imperialism, and its relationship to twentieth century history. In S. Sleeper-Smith, J. Barr, S. Stevens, N. Shoemaker \& J. O'Brien (Eds.), Why you can't teach U.S. history without American Indians (pp. 287-304). University of North Carolina Press.

Austin, D. (2007). All roads led to Montreal: Black Power, the Caribbean, and the Black radical tradition in Canada. The Journal of African 
American History, 92(4), 516-539. https://doi.org/10.1086/JAAHv92n4p516

Byrd, J. (2011). The transit of empire: Indigenous critiques of colonialism. University of Minnesota.

Canadian Museum of Human Rights. (n.d). https://humanrights.ca/

Cannon, M. \& Sunseri, L. (Eds). (2011). Racism, colonialism, and Indigeneity in Canada: $A$ reader. Oxford University Press.

Cooper, A. (2007, March 25). The invisible history of the slave trade. Toronto Star. https://www.thestar.com/opinion/2007/03/25

Cooper, A. (2021, April 4). My 30-year effort to bring Black studies to Canadian universities is still an uphill battle. The Conversation. https://theconversation.com/afua-cooper

Crenshaw, K. W. (2010). Twenty years of critical race theory: Looking back to move forward. Connecticut Law Review, 43 (5), 1253-1354. https://opencommons.uconn.edu/law review/11 $\underline{7}$

Dei, G. J. S. (1999). Knowledge and politics of social change: The implication of anti-racism. British Journal of Sociology of Education, 20(3), 395-409. https://doi.org/10.1080/01425699995335.

Delgado, R., \& Stefancic, J. (2001). Critical race theory: An introduction. New York University Press.

Delgado, R., \& Stefancic, J. (Eds.). (2013). Critical race theory: The cutting edge ( $3^{\text {rd }}$ ed.). Temple University Press.

Este, D., \& Sato, C. (2018). From multiculturalism to critical multiculturalism. In D. Ester, L. Lorenzetti \& C. Sato (Eds.), Racism and anti-racism in Canada (pp. 329-366). Fernwood Publishing.

Francis, A. (2019, August 7). The growing field of Black Canadian studies. University Affairs. https://www.universityaffairs.ca/news

Government of Canada. (2015, October 26). Discover Canada - Canada's History. https://www.canada.ca/en/immigration-refugeescitizenship

Government of Canada. (2021, June 11). Delivering on Truth and Reconciliation Commission calls to action. https://www.rcaanccirnac.gc.ca/eng/1524494530110/1557511412801

Green, J. (2006). From Stonechild to social cohesion: Anti-racist challenges for Saskatchewan. Canadian Journal of Political Science, 39(3), 507-527. https://doi.org/10.1017/S0008423906060215

Hogarth, K., \& Fletcher, W. (2018). Space for race: Decoding racism, multiculturalism, and postcolonialism in the quest for belonging in Canada and beyond. Oxford University Press.

James, C., Este, D., Bernard, W-T., Benjamin, A., Lloyd, B., \& Turner, T. (2010). Race \& well-being: The lives, hopes, and activism of African Canadians. Fernwood Publishing.

Kepinski, L. \& Hucke, V. (2017). Newsweek vantage: Achieving results: Diversity \& inclusion actions with impact. https://d.newsweek.com/en/file/459600

Leary, J. D. (2005). Post traumatic slave syndrome: America's legacy of enduring injury and healing. Uptone Press.

Li, Chris. (1995). The Chinese: a valuable asset to the Canadian Pacific Railway or an "evil" to White labourers? B.C. Historical News, 28 (3), 9-10. The Chinese: a valuable asset to the Canadian Pacific Railway or an "evil" to White labourers? - ProQuest

Lim, I. L. (2006). Here and there: Re/collecting Chinese Canadian history. Canadian Issues, Fall, 61-64. https://www-proquest-com.ezproxy.library

Logan, T. (2015). Settler colonialism in Canada and the Métis. Journal of Genocide Research, 17(4), 433452.https://doi.org/10.1080/14623528.2015.1096 $\underline{589}$

Ma, L. J. C., \& Cartier, C. (2003). The Chinese diaspora: Space, place, mobility, and identity. Rowman \& Littlefield.

Maitland, A. \& Steel R. (2020). Indivisible: Radically rethinking inclusion for sustainable business results. Young and Joseph Press.

Mamdani, M. (2015). Settler colonialism: Then and now. Critical Inquiry, 41(3), 596614. https://doi.org/10.1086/680088

Mar, L. R. (2007). Beyond being others: Chinese Canadians as national history. BC Studies, 156(Winter), 13-34. https://doi.org/10.14288/bcs.v0i156/7.608 
Martinez, M. L. (2015, April 30). Leveraging cultural competence for inclusion [conference presentation]. 6th Annual Florida Diversity \& Leadership Conference. https://slideplayer.com/slide/4743307/

McCallum, M. J. (2012). Condemned to Repeat? Settler Colonialism, Racism and Canadian History Textbooks. In R.J. Gilmour, D. Bhander, J. Heer, \& M. C.K. Ma (Eds.), In Too Asian? Racism, Privilege, and Post-Secondary Education, (pp. 67-79). Between the Lines Press.

McLerran, J. (2019). Theorizing settler colonialism: Alternative Indigenous methodologies. Feminist Studies, 45(2-3), 455-466. https://doi.org/10.15767/feministstudies.45.2$\underline{3.0455}$

Ngo, H-V. (2018). Racism in Canadian education. In D. Ester, L. Lorenzetti \& C. Sato (Eds.), Racism and anti-racism in Canada (pp. 175-200). Fernwood Publishing.

Orford, S. (2021, February 24). Black Studies programs you should know about. The Star. https://www.thestar.com/life/post secondary ed ucation/2021/02/23/black-studies- programsyou-should-know-about.html

Razack, S. H. (2012). Memorializing colonial power: The death of Frank Paul. Law \& Social Inquiry, 37(04), 908-932. https://doi.org/10.1111/j.17474469.2012.01291.x

Razack, S. H. (2020). Settler colonialism, policing and racial terror: The police shooting of Loreal Tsingine. Feminist Legal Studies, 28(1), 120. https://doi.org/10.1007/s10691-020-09426-2

Stevenson, Bryan (2014) Just Mercy: History of Justice and Redemption. Spiegel and Grau.

Sue, D. W., Capodilupo, C. M., Torino, G. C., Bucceri, J. M., Holder, A. M. B., Nadal, K. L., \& Esquilin, M. (2007). Racial microaggressions in everyday life: Implications for clinical practice. American Psychologist, 62(4), 271-286.

Sussman, R. W. (2014). The myth of race: The troubling persistence of an unscientific idea. Harvard University Press.

Tator, C., \& Henry, F. (2010). The struggle for antiracism, inclusion, and equity in the Canadian academy: Representation is not enough. Our Schools, Our selves 19(3), 369-398.

Trudel, M. (1994). Dictionnaire des esclaves et de leurs proprietaires as canada francais $\left(2^{\text {nd }}\right.$ ed.). Hurtubise.

Truth and Reconciliation Commission of Canada (2015). Truth and Reconciliation Commission. https://web.archive.org/web/

Vallée, J. (2018). Eurocentrism in the curriculum: A barrier to Indigenous student success. Vanier Academic Voices, 1 (1), 8-9.

Veracini, L. (2010). Settler colonialism. Palgrave Macmillan

UK. https://doi.org/10.1057/9780230299191

Wolfe, P. (2006). Settler colonialism and the elimination of the native. Journal of Genocide Research, 8(4), 387409. https://doi.org/10.1080/14623520601056240

Zha, Qiang. (2019, September 5). Chinese students in Canada: Attitudes, opportunities, and challenges. University of Nottingham Asia Research Institute. https://theasiadialogue.com/2019/09/05 


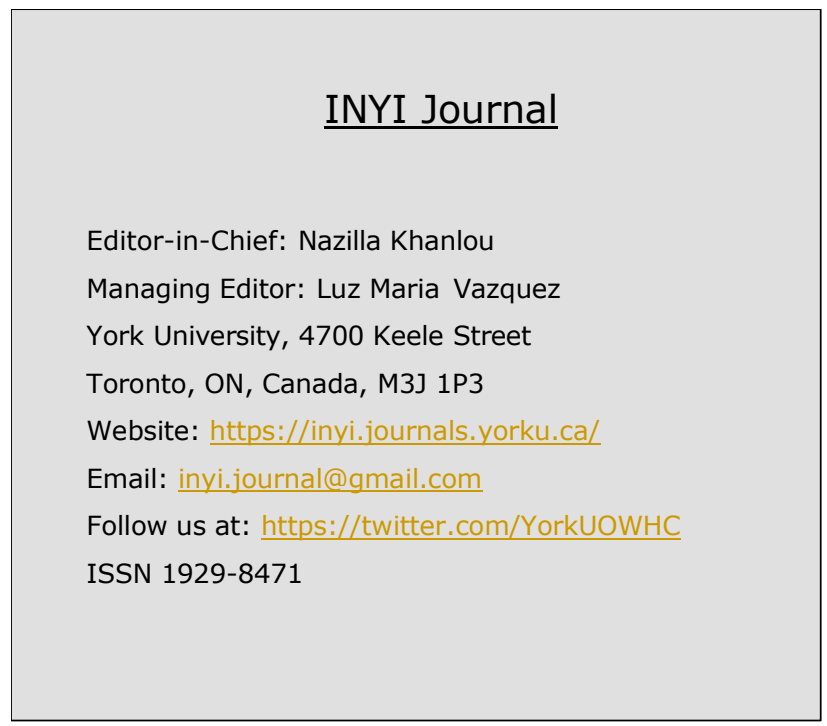

